\title{
Enhancing Students' Speaking Through the Process of Performing Drama
}

\author{
Dian Anggraini \\ English Department of Education Faculty \\ State Institute for Islamic Studies (STAIN) Salatiga \\ diananggraini@gmail.com
}

\begin{abstract}
An action research has always been interesting thing for teacher because the root of it is taken from their own problems. This study is a self reflection of a problem that is faced by the researcher. It focuses on a certain activity in a certain class and at a certain period of time. Questionnaires, interview sheet, observation sheet, students' worksheets, and teacher's lesson plans serve as data resources. The result shows a significant increase in the students score. However, there is variation on the general result.
\end{abstract}

Keywords: collaborative learning, drama, motivation

\begin{abstract}
Abstrak
Penelitian tindakan selalu mengundang ketertarikan bagi guru karena akarnya diambil dari masalah mereka sendiri. Meskipun tidak selalu mudah untuk mengakui dan mendefinisikan hal seperti itu. Penelitian ini merupakan refleksi dari masalah yang dihadapi peneliti. Ini berfokus pada aktivitas tertentu di kelas tertentu dan pada waktu periode tertentu. Kuesioner, lembar wawancara, lembar observasi, lembar kerja siswa, dan RPP guru berfungsi sebagai sumber data. Hasilnya menunjukkan peningkatan yang signifikan pada nilai siswa. Namun, ada variasi pada hasil secara general.
\end{abstract}

Kata Kunci: Pembelajaran Kolaboratif, Drama, Motivasi 


\section{Introduction}

Speaking activity is practically abandoned in junior high school level. Teachers are concerned with national examination. That is the reason the research is taken the interest for choosing this topic also lies in the development of teaching and learning in the researcher's environment, such as the schools' atmosphere, students' interests and teachers' attraction.

The researcher prefers to choose this topic because she finds that a classroom consists of a number of students at least 25 percent of it is still having trouble speaking in English. Their reason is mostly shy but some of them admitted to have very little understanding about English lesson.

The speaking activity chosen for this research is drama because it can promote interaction. Richard and Lockhart (2000: 138) point out that a common theme underlying different methods of language teaching is that second language learning is a highly interactive process. The Interaction Hypothesis argues that it is in the interaction process that acquisition occurs, that learning is acquired through talking with others (Johnson, 2002: 95). Furthermore, Ellis (1986: 127) states classroom teaching should be treated as interaction. It can be assumed that the language used in the classroom affects the nature of the interaction, which in turn affects the opportunities available for learning. Therefore, the study of interaction is critical to the study of language classroom learning. 


\section{Drama}

The use of drama as a method to improve students' speaking relates with the genre used for the VIII grade as it is stated in the curriculum that is narrative, and it concerns with the need of the problem.

Zalta (2006) describes using drama in the young learner classroom gives children who are shy when speaking a foreign language a character to "hide behind". It also helps children to activate language and have fun. Using drama activities has clear advantages for language learning. It encourages them to speak and gives them the chance to communicate, even only through learned dialogues. Drama in education was first brought by Winifred Ward, a teacher of Northwestern University's School of Oratory, who introduced Creative Drama for language learner for the first time. Although it has rather different objectives, when it is used for second language learner, the main point lies in the using of the method.

Liu (2002: 6) believes that in second or foreign-language classrooms, there are generally two options in teaching. One option is Focus on Forms, and the other is Focus on Meaning. Liu also states Process Drama requires language to be used in meaningful, authentic situations, where the focus is on posing questions and seeking answers to those questions. In drama, learners study with other learners through asking and answering and then if they really can understand the meaning of it, expressing them in their own way. It is stated that when a lesson focuses on meaning, they are often interesting, because it is relevant to their social life. 
According to Lewis and Rainer (2005: 10) in order to be practitioner in drama, here are several things their students should have, they are:

1. Personal and social abilities

2. Performance skills

3. Knowledge and understanding of theatrical ideas and concepts They also emphasize that every element is so important for a drama to succeed.

Lewis and Rainer (2005:13) summarize the concept of drama into seven broad categories. They are role, form, structure, stage, text, audience, and content. Those categories are not the main concern here but the actual performance and how the students conduct it using narrative stories. The writer would like to investigate the students' ability to relate the language into their performance. The use of narrative as the story represents part of the curriculum that is used today. The drama will be performed in a group, so the researcher will also use a collaborative method.

\section{Natural-Conversation Speech}

Conversation according to Zaida (2008) can be defined as the informal interchange of thoughts and information. A naturalconversation flows on itself. If we look closer, we can infer that it covers (1) question -and answer- play, a major role in general conversation dynamics; (2) the building of one comment on another.; (3) it has specific feature of the English used such as: the use of contraction (I'll, I'm, you're, etc), the occasional use of colloquialism, the use of exclamation, 
and the use of transition expression, such as by the way, incidentally, that reminds me, as a matter of fact, in other words, in any case, any way, etc.

Creating a natural-conversation based on narrative story is autonomy. To make it as natural as possible, we need to include the above elements into the script of the drama.

The preceding activity before drama for students can be, for example,miming activity. Children use gesture or actions to indicate a thing or situation. Here teacher can establish the activity by doing other variation. Watching video can be a language learning also. There are many variations to use the video. Here are a few: (1) Students watch a fragment, a video sequence with no sound, and guess what happens. Students then create a dramatic scene based on what they have watched. By the end of the activity, the video is replayed again this time with sound so students can compare their version with the video. (2) Students do not watch, but only listen and try to guess what happens and where the events take place. Students then create dramatic sequence based on what they have heard. Students then watch the video again and compare their version with the video. (3) Students watch only a very short fragment and then predict its continuation. Students then act it out. When they watch the continuation from the video, they can compare their version.

Transforming stories into mini plays requires several things, such as: (1) choose simple stories for students; (2) create scripts for the stories, adjust them to the situation in your class; (3) if necessary, have students prepare costumes and supporting aids; (4) put on play for other classes and/or parents.

Brown (2001: 184) explains that drama is a pre-planned form of role-play or simulation. The use of story line or script is essential. 
Writing the story line or script and rehearsing was part of the activity. With large classes, the activity can be done in groups. Furthermore, each group can create their own interpretation to the story.

\section{Collaborative Learning}

Gunawan (2003: 198) stresses that Collaborative Learning is not just a learning process collaboratively but also it involves a fair communication process in the class. He believes there are five important elements in a collaborative learning, they are:

a. Positive Interdependent

b. Supportive face to face interaction

c. Personal and group responsibility

d. Personnel communication ability and communication in a small group (developing trust, leadership, decision making, good management and conflict resolution)

e. Learning process in groups (reflecting a function, forming ability to cooperate in a group, and developing better achievement together)

It is believed that a group work would not succeed if members of the group do not realize the important of those elements. In order to achieve that, teachers need to supervise and facilitate. Grouping should be arranged carefully and it needs good planning, consistent and systemic.

The negative side of collaborative learning needs to be considered. There are possibilities that might arise, such as:

a. Smart students might feel at disadvantage, if they do not fully comprehend the real goals 
b. Those students would also object because the assessment would be based on group' work achievement.

c. There is a possibility that the group would not work well, only some students are busy while others only play around and later rely on them.

On the other hand, socially it is good to have collaborative learning. Gunawan (2003: 203) states the positive sides of collaborative learning are:

a. extend interpersonal ability,

b. extend social communication among students,

c. increase empathy for others,

d. learn leadership and management,

e. learn organization, working as a team

\section{Motivation}

Learning a second language needs motivation. For children in junior high school age, it is needed and teachers should provide it. Brown (2001: 72-73) offers definition of motivation; that is the extent to which you make choices about (a) goals to pursue and (b) the effort you will devote to that pursuit. In view of that, teachers need to mention their learning goals to students.

It is important for students to understand what is expected of them. It becomes their intrinsic motivation. If a student has understood, the teaching and learning process would succeed by itself.

Brown (2001: 81) also reminds teachers to think not so much as a teacher who must constantly "deliver" information but more as a "facilitator". Teachers should set the stage for learning, start the wheels 
turning inside the heads of their students, turn them on to their own abilities, and help to develop their ability.

Number of students in a class is also an important factor. As Long (2000: 76) states that each child is an individual with a unique ability and characteristic style. Children's personality can also affect the learning process since this shapes the way in which they relate with others. Based on this assumption, the writer will take some consideration throughout the research.

\section{Action research}

In investigating the effectiveness of a teaching and learning process, using an Action Research is the most appropriate methods to work with. As stated by Glanz (1982: xii) that action research is devoted to specific strategies and techniques.

Teaching English in junior high school should integrate four skills of competence, speaking, listening, reading and writing. In simple way, English teacher says written cycle and spoken cycle. The focus of this research will be on the spoken cycle.

Furthermore, Harmer's (1998:4) says that students are the people who need the practice, in other words not the teacher. In general terms, therefore, a good teacher maximizes STT (Student Talking Time) and minimizes TTT (Teacher Talking Time). Thornbury (1998: iv) states that speaking is interactive and requires the ability to co-operate with others.

Therefore it is necessary to have speaking class conducted for students. Not only it will give them the opportunity to practice how much English knowledge they have but also learn from other. It is also quite important for English teacher to speak English in the class. 
In order to maximize speaking opportunity and increase students' experiences in language used in a speaking classes, teachers should also provide feedback. It is best given when the activity has ended.

Thornbury (1998: 89) also states that drama is one of speaking class activities. Therefore in this research, drama is the main activity being investigated.

Drama activity chosen for this speaking class has gone through many considerations. Time allotment, school environment, teaching situation, and mainly students' interest come to mind. The VIII A of Pius Junior high School students as the subjects of the research are chosen because of their lowest average score among other classes. The class consists of 15 female and 16 male students. For the drama activity in the first cycle, the class is divided into 5/6 group members mix gender. Later based on reflection from the first cycle, there is regrouping for drama in the second cycle.

In the third cycle, the researcher is getting more confident. The drama is great. Finally, it can be inferred that drama is good for speaking class.

\section{Research Method}

Here is the scheme of the research; it showed how the action research ran. There were 3 cycles involved. 


\section{Figure 1 Research Scheme}

VIII A students tended to speak

Indonesian in English class. The reasons were:

- Shy

- Not confidence

- Unsupportive environment

- $\quad$ no reward (no score for speaking)
Plan 1: The teacher asked the students to retell

a story by the end of narrative

Act 1: teacher conducted retelling story

activity

Observe 1: 55\% got above Passing Grade

(PG) score and $45 \%$ got below PG score

Plan 2:

- Teacher used drama in the speaking class

- Students would do drama collaboratively

Act 2: Teacher conducted drama in speaking class. Students worked in groups. The groups were arranged by teacher based on students score in previous cycle.

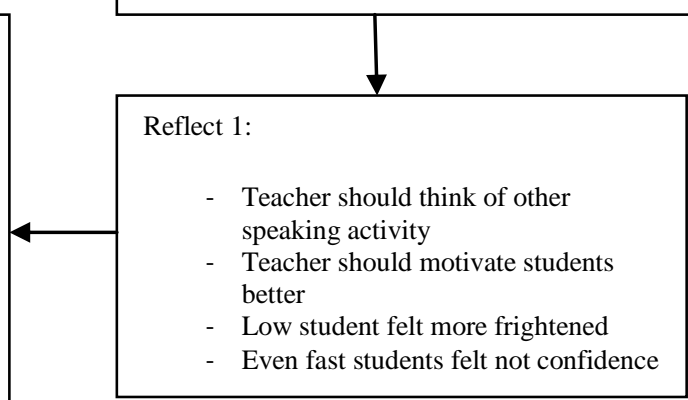

Observe 2: $68 \%$ got above PG score and $32 \%$ got below PG score.

\begin{tabular}{|c|c|c|c|}
\hline $\begin{array}{l}\text { Plan 3: The teacher } \\
\text { planned another } \\
\text { cycle. Students } \\
\text { would perform } \\
\text { drama with friends } \\
\text { they chose } \\
\text { themselves }\end{array}$ & $\begin{array}{l}\text { Act 3: teacher divided } \\
\text { students in } 3 \\
\text { categories. Good } \\
\text { score students, fair } \\
\text { and poor. The good } \\
\text { groups chose friends } \\
\text { from the poor group, } \\
\text { then from the fair } \\
\text { group until there was } \\
\text { no student left. } \\
\text { When the groups } \\
\text { were arranged, they } \\
\text { performed drama } \\
\text { with the new group. }\end{array}$ & $\begin{array}{l}\text { Observe } 3: 97 \% \\
\text { passed the Passing } \\
\text { Grade score and } 3 \% \\
\text { did not pass the PG } \\
\text { score }\end{array}$ & \begin{tabular}{|l} 
Reflect 3: \\
- \\
Drama's \\
performances were \\
better \\
- VIII A Students \\
practiced speaking \\
English in English \\
class. \\
- There was one \\
student who did not \\
passed the Passing \\
grade. He would get \\
further assistant.
\end{tabular} \\
\hline
\end{tabular}


The research subject was chosen based on pre-cycle activity. The result was VIII A class of PIUS Junior High School in the 2009/2010 school year.

The data analysis was based on questionnaires, interview sheet, observation sheet, students' worksheets, and teacher's lesson plans.

\section{Result}

Based on observation, in spoken cycle students of Junior high school faced such problems:

Table 1 List of Weaknesses

Weakness

1. Slow learners had problem with technical term.

2. Slow learners had trouble in determining the technical term.

1. Slow learners had problem with understanding the story.

2. Slow learners were confused in determining the concept.

1. They did not have enough vocabulary.

2. They were too confused even to start their own story.

3. They did not know how the concept of sentence worked.

1. Slow learners were shy with their works.

2. In a group, slow learner depended a lot on the fast learner.

3. Because students were not confidence with their works as a results, they were shy their performance.

4. Only fast learners excelled both in writing and speaking.

5. Sharing could be hard for those who had never done it.

6. The atmosphere of the English class was not conducive because the gap and the competition reflected.

Then later after the action research was taken the result could be seen from the figure below: 
Figure 2 Student's Recapitulation

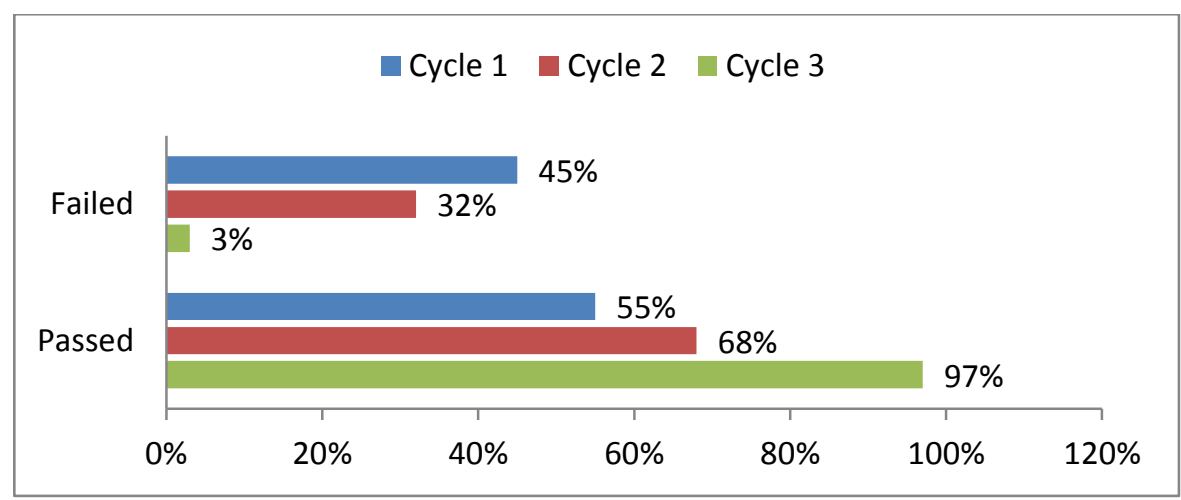

After conducting the classroom action research, I as the English teacher of PIUS Pekalongan Junior High School got better understanding of my teaching. From the result of my research, I found the weakness of my teaching. They can be elaborated as follows:

(1) I did not approach my student in person. I only told them things and expected them to follow. I should have listened and paid attention better to all students.

(2) I was lacking in instructional approach in conducting speaking class. I should have consulted teaching method text book more.

(3) I did not talked English in class. I think that was one of the reasons that my students were lacking in pronunciation. I found that it was the most question asked to me. "How to say this word?" etc.

I found that students who thought English was difficult, they tended to ignore the lesson. They tried to do the assignment without understanding what it was. They just copied from others. By doing creative drama, they became involve in the teaching and learning process. The most important thing was they had an English environment. 


\section{Conclusions and Suggestions}

The conclusions that can be taken from the research are:

(1) In order to absorb the lesson in a classroom students need to build up their motivation. The role of a teacher is very important in creating such motivation.

(2) Learning second language needs a supportive environment. A teacher needs to be able to create a good atmosphere in a classroom.

(3) With an appropriate activity students can explore their competence actively.

Based on the result of the research, the following are some suggestions for readers, including students and teachers:

(1) Students

Speaking class is done in order to provide students with English setting; all students should not feel terrified because of it. A lot of practice would make perfect. Students of junior high school are capable of having conversation in English in daily life. That is why they should not feel shy.

(2) Teachers

Teachers should understand their students' need and problems so they can give the best treatment to overcome the problem. Teachers should be able to motivate their students in various ways.

(3) Schools

The English teaching and learning process in SMP PIUS Pekalongan get better quality and to motivate other teachers to do their analysis on their teaching and learning process. 


\section{References}

Brown, H. Doughlas. 2001. Teaching by Principles: An interactive Approach to Language Pedagogy $2^{\text {nd }}$ Edition. New York: Pearson Education Company.

Ellis, Rod. 1983. Understanding Second Language Acquisition. Oxford: Oxford University Press.

Glanz, Jeffrey. 1982. Action Research: An Educational Leader's Guide to School Improvement. Norwood: Christopher-Gordon Publishers, Inc.

Gunawan, Adi W. 2003. Genius learning Strategy. Jakarta: PT. Gramedia Pustaka Utama

Harmer, Jeremy. 1998. How to Teach English. Malaysia: Pearson Education Limited

Lewis and Rainer, Martin and John. 2005. Teaching Classroom Drama and Theater. USA Rutledge.

Liu, Jun. 2002. Body and Language. Intercultural Learning Through Drama. Process Drama in Second - and Foreign - Language Classrooms. $\quad$ European Medi@Culture-Online http://www.european-mediaculture.org (accessed on 15 April 2010)

Long, Martyn. 2000. The Psychology of Education. London: Routledge Falmer

Thornbury, Scott. 2005. How to teach Speaking. Malaysia: Longman

Richard, J.C and Lockhart. 1994. Reflective Teaching in Second Language Classroom. United States of America; Cambridge: CUP

Zaida, Nur. 2008. Using Dramatization in Encouraging EFL Students Engage in Natural-Conversation Speech. A paper. The $5^{\text {th }}$ national JETA Seminar Sanata Dharma University 30 June - 1 July 2008.

Zalta, Galina. 2006. Using Drama with Children. English Teaching Forum, p. 24-27, 46. 